\title{
絧フィブロインの延伸にともなら内部微細構造の変化*
}

\author{
信州大学維維学部平林瀿・石川 博 \\ 大阪大学蛋白筫研究所 角戸 正夫
}

\section{CHANGES IN THE INTERNAL FINE STRUCTURE OF SILK FIBROIN BY DRAWING}

By Kiyoshi Hirabayashi**, Hiroshi Ishikawa** and Masao Kakudo***

(**Faculty of Textile Science and Technology, Shinshū University, Ueda City, Nagano Prefecture, Japan)

(***Institute of Protein Research, Ōsaka University, Jōan-cho, Kita-ku, Ōsaka, Japan)

Effects of drawing on the $\alpha-\beta$ transition and the formation of voids in Tussah silk fibroin wexe studied by means of $X$-ray diffraction at wide and small angles, polarizing microscopy, and electron microscopy.

1) It is found that the fibroin coagulated in silk gland has a morphology of small spherulitic particles (ca. $240 \mathrm{~A}$ in radius) in which hydrophobic residues in the polypeptide are arranged in the inner part and the hydrophilic residues in the outer part. This structure is destroyed by the drawing of gel. The $\alpha$-helix form of the molecule changes gradually into the exteuded $\beta$-form as the draw ratio increases : the $\beta$-component becomes predominant at the draw ratio higher than 6-8 times. However a small amount of $\alpha$-conformation still remains even at the highest draw ration 14 . The crystallinityof the specimen ( $36 \%$ at the beginning) decreases at furst but turns to increase, having a minimum at the draw ratio of 8 . On the other hand, the birefringence increases slowly but monotonously as the draw ratio.

2) The mechanism of the void formation as well as the effects of drawing on their shapes was examined through use of microscopies and a small-angle $X$-ray method. It is considered that the formation of voids is caused by the emission of water which have been occluded in the gel. Such voids become smaller and longer by drawing the gel and align in the direction of the fiber axis, the ratio of the length to the width of the voids attaining two.

(Received August 26, 1968)

\section{1. 緒言}

熟虫期にいたると寔は蛹体保護のため䋧采を吐出し数 日にして蔽壳を造成する。この紡系機構に関しては綟フ ィブロイン溶液にずり伈力を加えると緎維化するので, 機械的变性作用により絹䒺が形成されるものと考えられ ている゙。

しかし編杀腺内䋧フィブロインがいかなな内部擈造上 の恋化を受けながら䋐維化するかは現在のところ明確な 実験的根贱がない。

*この報交を「綗フィブロインの微細槽造に咸する研 究 (第 10 報) 「Studies on the fine structure of silk fibroin (Part 10)」とする。”
そこでわれわれは構造がかなり明らかにされている拃 查フィブロイン゙）突駼に供し延伸にとすなら内部微綀 構造の变化を $\alpha-\beta$ 転移とボイドの形成に焦点をむて実 験を行ない若干の知見を得たので報告する。

\section{2. 実験試料および方法}

\section{$2 \cdot 1$ 実呀試料}

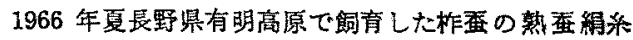
腺内フィブロインを用いた。を寺昍系を始めた頃を見計 らって䖽体を解剖し，直ちに $1 \%$ 酢酸溶液に浸せきし所 定の倍率に延伸した。最高延伸倍率は 14 倍であった。

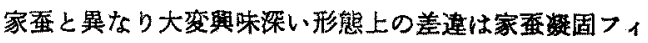
ブロインは乾學凝固させると水に溶解しないが柞雷㠜固 
フィブロインは水によく溶解し分散することである。分 散する様子は肉眼で観察できる。

\section{$2 \cdot 2$ 実験方法}

\section{$2 \cdot 2 \cdot 1$ 顕微鏡による観察}

柞䄈系の表面構造および延伸にともなら断面の様子を 検鏡した。表面構造は光学顕微鏡および電子顕微鏡で調 べた。断面の様相は厚さ $24 \mu$ の切片とし光学顕微鏡で 観察した。

\section{$2 \cdot 2 \cdot 2$ 錫 增 量}

$50 \%$ （比重 $=1.271 ） の \mathrm{SnCl}_{4} \cdot 5 \mathrm{H}_{2} \mathrm{O}$ 溶液を $60^{\circ} \mathrm{C}$ に 保ち 1 時間絹糸を漫せきしたのち水洗, 乾燥し錫增量を 行なった, 以後同様の処理を繰り返えした。

\section{$2 \cdot 2 \cdot 3$ 示差熱分析}

試料は粉末状とし円筒状石英セルに満し, 理学電機製 卓上型示差熱分析装置を用い, 昇温速度 $5^{\circ} \mathrm{C} / \mathrm{min}$. chart speed $5 \mathrm{~mm} / \mathrm{min}$. DTA 感度 $1 \mathrm{mV}$ で自記記録せしめ た。

$2 \cdot 2 \cdot 4$ 含 水 量

各試料を常温で室内に放置したのち, $105^{\circ} \mathrm{C} て ゙ 2$ 時間 乾燥したのち秤量し含水量を求めた。

$2 \cdot 2 \cdot 5$ 複. 屈折

ペッケ法により $n_{\|}$・ $n_{\perp}$ を求め $n_{\|}-n_{\perp}$ より複屈折を 算出した。光源はナトリウムランプ，浸液はブチルステ アレート・トリクレジールホスフェートの混合夜を用い た。

$2 \cdot 2 \cdot 6$ 結晶化度

理学電機製ガイガーフレックスを用い試料はできるだ
け粉末状にし試料板につめ $35 \mathrm{kV}, 15 \mathrm{~mA}$, Ni filter で沪光した $\mathrm{Cu} K_{\alpha}$ 線を用い干渉強度曲線を自記記録さ せた。非晶部分の散乱強度は非晶性フィプロインフィル ムを用いた非晶質フィルムは製膜時 $100^{\circ} \mathrm{C}$ で乾燥したる のでめる。この非晶質フィルムの干渉強度および空気の 散乱を差し引き面積比から結晶化度を算出した。

$2 \cdot 2 \cdot 7$ 小角散乱像

理学電機製強力X線発生装監を用い $40 \mathrm{kVp} .80 \mathrm{~mA}$. $\mathrm{Ni}$ で沪光した $\mathrm{CuK} K_{\boldsymbol{a}}$ 線を用い, 写真法の場合は 3 時間 撮影時間をかけた。

コリメーションは第 1 コリメーターと第 2 コリメータ 一は $0.5 \phi ， 0.3 \phi$ のスリットを用い，カウンター法の 場合は $0.5,0.3$ とした。散乱スリットおよび受光スッ ットは $0.3 ， 0.1$ を用いた。

\section{3. 結果および考察}

\section{1 絹糸の外観}

綟糸を顕微鏡下で観察すると, 柞虫糸においては無数 のたてじまが観察される。第1図（c）は倍率 100 の場合 であり，第 1 図(b)は 400 の場合である。明らかに緇維 軸方向に沿ってたてじまが存在する。これに反し第 1 図 (a)のよらに家叠系の場合にはこのようなしま模様は見 られない(電顕像では認められる)。第 2 図は柞䖽糸の レプリカ法による電顕像であるが，同様のたてじまが認 められる。なお柞龺糸を微細片とし水中に浸し観察する としま模様のところが透明に見觉る。これは水の浸入を 亦すものである。

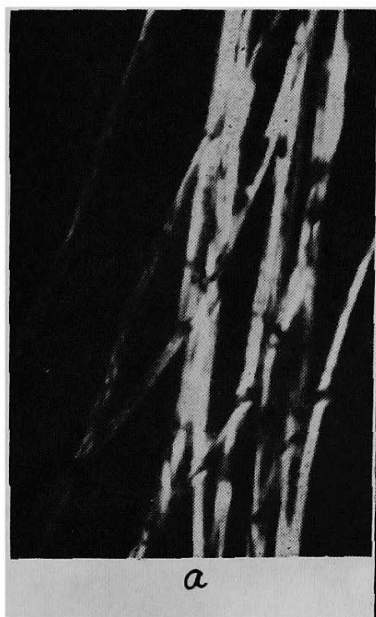

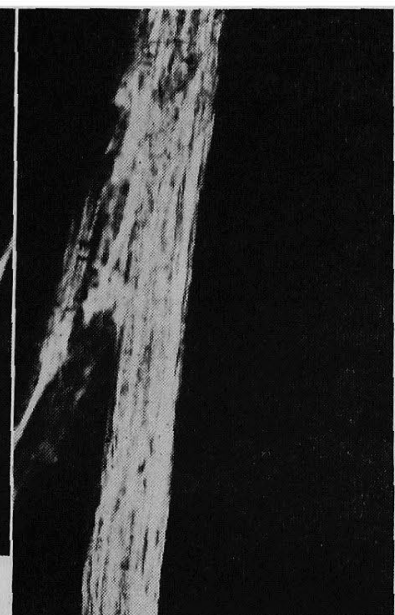

b

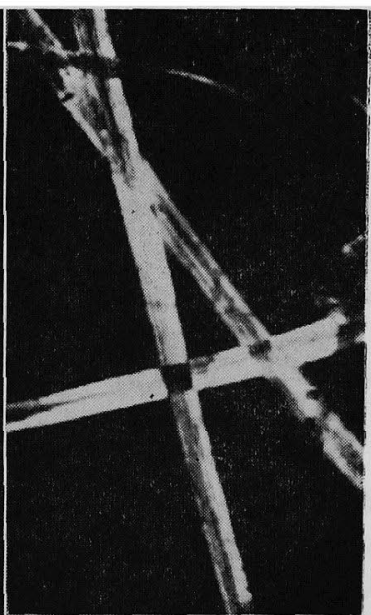

C

Fig. 1. Optical micrographs of silk fibers a : domestic silk $(\times 100), \quad b:$ Tussah silk $(\times 400)$ c : Tussah silk $(\times 100)$ 
第 3 図 (a)，(b)，(c) はそれぞれ 5 倍，12 倍延伸テグ スおよび単㵶維の断面の顕微鏡写真である。延伸倍率の 小さいむのには大きい, 延伸倍率の大きいものには小さ い空隙が観察される。鏡筒を上下寸ると空隚は消失し他 の空隙が現われてくるので, 㵶維軸方向にはそれほど長 いものでないことがわかる。それゆえたてじまはフィブ リルとフィブリルの境界線に相当するものと思われる。

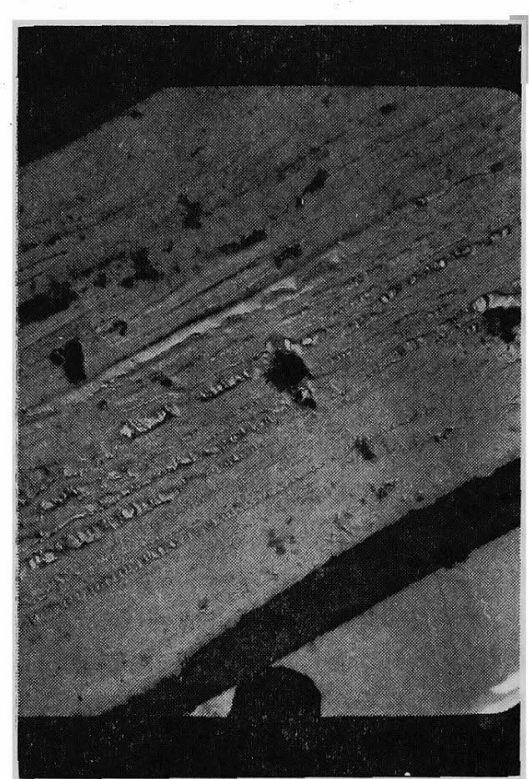

Fig. 2. An electron micrograph of Tussah silk fiber $(x 12000)$

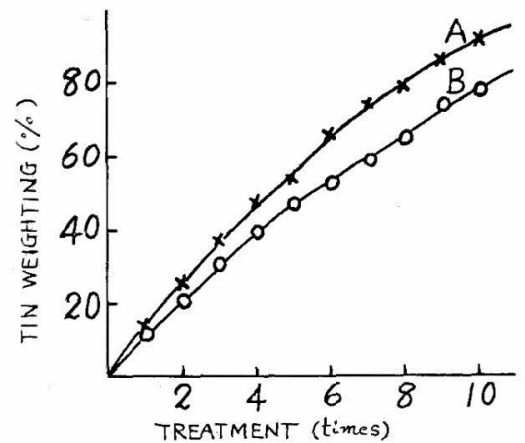

Fig. 4. Tin weighting of silk fibers as a function of the treating time.
A : Tussah silk
B ; Domestic silk

\section{2 錫 增 量}

第 4 図は家亘糸, 柞亘系に対する錫増量の結果であり 横軸は処理回数を縦軸は増量率を表わしている。処理回 数の増加につれほぼ直線的に増量される。坂口 ${ }^{3)}$ の研究 によると塩化錫溶液は織維の空陵に浸入し, 水洗, 乾燥 すると凝縮し酸化錫として空隙内の一部に沈着する。ふ たたび酸化錫溶液に浸すと瀻維は膨潤し空隙に塩化錫溶 液が漫入する。このようなことが処理ごとにおこなわ れ，繊維の空隙に沈着してゆくのである。このような錫 増量の叔こなおれることからも絹系に括けるポイドの存 在がらかがわれる。

\section{3 含 水 量}

第 5 図は延伸にともなら含水量の変化を示したもので ある。未延伸凝固フィプロインはわずかながら延伸糸に くらべ水分を吸着している。しかし延伸倍率を変えても

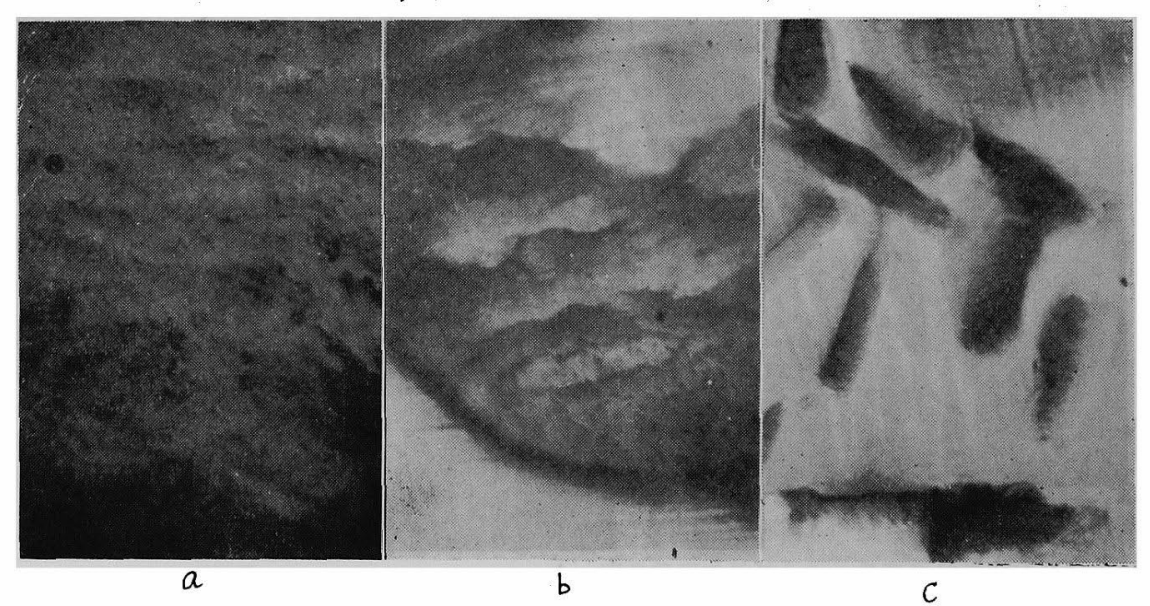

Fig. 3. Optical micrograhs of cross sections of Tussah silk guts $(\times 400)$ Draw ratio: a ; $\times 5, \mathrm{~b} ; \times 12$, c ; fiber 


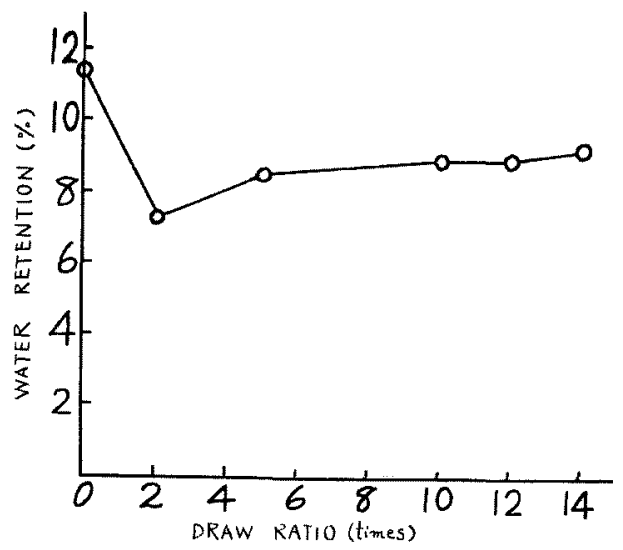

Fig. 5. Relation between the water retention and the draw ratio.

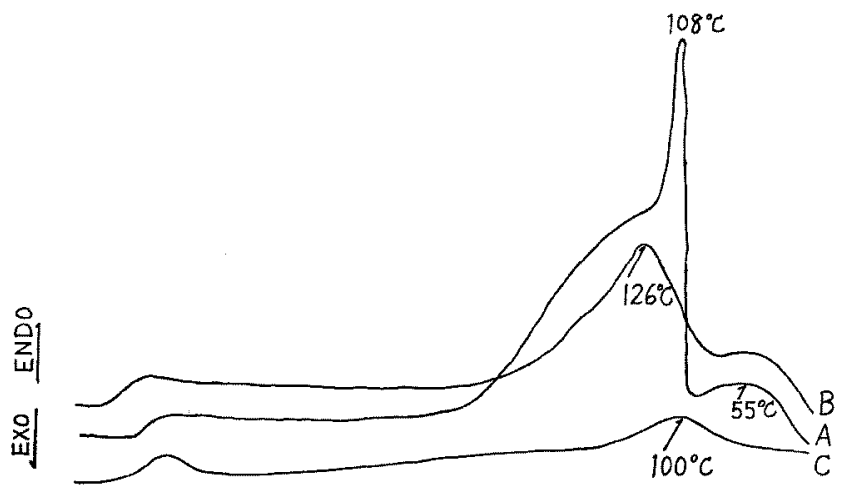

Fig. 6. Thermograms for Tussah silk fibroin
A ; silk gel, water $50 \%(w / w)$
$\mathrm{B}$; coagulated silk gut, water $30 \%(\mathrm{w} / \mathrm{w})$
C ; silk fiber

含水量に変化のないこと忧延伸にともない契質的にはボ イドの容積には変化を来さないるのと思われる。なお緎 維形成時に戴維中に含まれたボがボイド形成の原因とな ることについては後で詳しくのへる。

\section{4 凝固フィブロインの構造}

柞蟫フィプロインの 2 次構造についてはそれが絹系腺 内にあるらちは $\alpha$-helix 構造をとり，静かに乾燥凝固 すれば $\alpha$-helix 構造を含んだ状態で結晶化することを 前報で報告した。それで編糸腺内で $\alpha$-helix 掅造を とるフィブロイン分子が延伸によりいかなる举動を示す かX線的以険颜を行なっだ。

まず絹系腺内凝固フィプロインの形態はそれが水にた やすく溶解することから柾水性の基を内儧に親水性の基 を外側に向け球状粒子として水分子にとりかこまれ結晶 化しているむのと考えた。このことは小角散乱像からむ
支持される。すなわら 240 A に相当する 干涉環が凝固フィブロイン化存在すこ とである。X線による干渉は電子密度の 踈密によりひき起すので240Aの年涉環 はフィブロイン分子を球状粒子と仮定す ると粒子間の距離に相当する。跼系腺内 ではこれら粒子が規則的配列をしていな いことはX線図が線幅の広い干涉謤を示

すことから明らかである。

\section{5 超伸にともなう $\alpha-\beta$ 転移}

昩系された緎維に存在する空隙は絹禾

眿内液状絹の延伸とどのような関係にあ るか考察する前に液状絹が延伸作用要受 け内部構造上どのように变化するかる調 ベた。

ます㔻体を解剖し絹杀腺を蒸留水で洗

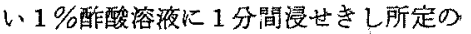
長さに延伸したのちX線により結晶化度 $\varepsilon \alpha-\beta$ 転移を,ベック法に上り複屈折 （配列度）を湘定した。

第 7 図は延伸にともなら干涉強度曲線 を赤道線上に沿って自記記録ざせたもの である。延伸倍率の增加につれ $\alpha$ 型から $\beta$ 型へ転䔟する様子が明瞭に示されてい る。すなわら 型に特有な $7.4 \mathrm{~A}$ と 3.7 $A の ヒ ゚ ー ク は \beta$ 型に特有な $5.30 \mathrm{~A}, 4.30$ A と転移する。4倍延伸ではわずかに 型への改候が表われ 6〜8 保になると, $\beta$-rich になり延伸倍率の增加ととるに $\beta$ 化が進む。14倍に延伸してもな招 $\alpha$ 型 棈造の残存が認められる。

さらにこれと並行して測定した結晶化度（第8图）は 未延伸凝国フィブロインで $36 \%$ である延伸にともない 結晶化度は減少し， $\alpha$ 型と $\beta$ 型の混合比の逆転する 6 8 倍近辺で最少を示し以後增加の傾向をたどる。

これに反し複屈折（第9図）は延伸にともないじょじ ょに增加する。延伸倍率が 8 倍前後になって子結晶化度 のよらに低下しないのは, 複屈折が分子の配向に依存し ているからと思和れる。

\section{6 延伸にともなう小角散乱像の変化}

未延伸凝固フィブロインの小角散乱X線図に表われる 特徵は $240 \mathrm{~A}$ に相当寸る干橴䍗の存在である。広角 $X$ 線 図に拈ける強度最大の $7.4 \mathrm{~A}$ 括よび broad $3.7 \mathrm{~A} の$ 干啮か;， poly-L-alanine $\sigma \alpha$ 型結晶の粉末因形仁一致 すること虾，赤外 2 色性よりアミドIが $1650 \mathrm{~cm}^{-1}$ に平 行色性を，アミド円が $1535 \mathrm{~cm}^{-1}$ に垂直色性を示すこ 


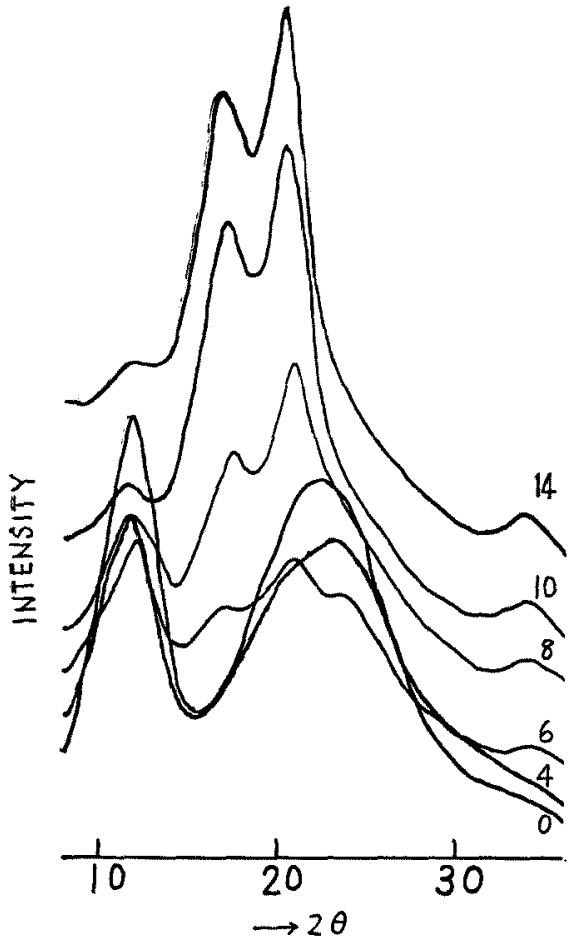

Fig. 7. X-ray diffraction intensity curves of Tussah silk guts drawn at various ratios.

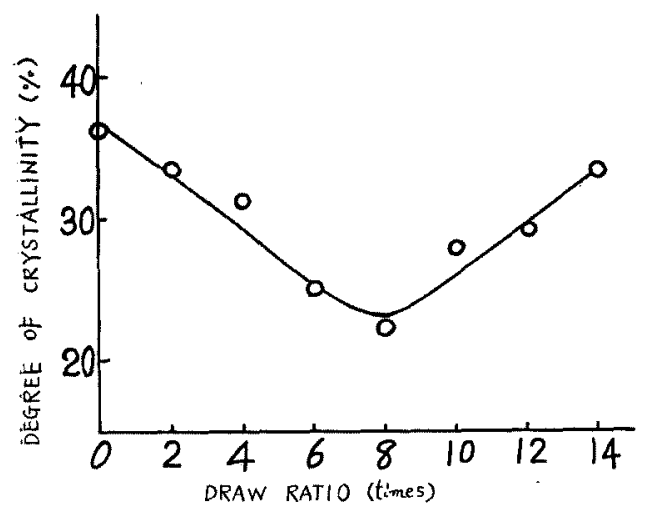

Fig. 8. Effects of drawing on the crystallinity (determined by $\mathrm{X}$-ray method) of Tussah silk gut.

と4)から末延伸凝固フィブロインにおいては，そのタミ ノ酸組成に执いて約 50\%のアラニン残基を含むことと あわせ考え， $\alpha$-helix 構造を狩つ poly-L-alanine が含 有されていることは明らかで岁る（1本の分子中に ala nine 単位がかなり速続して結合している部分があるう。 小角散乱X線图に抋いて $240 \mathrm{~A}$ の渋環の存在は、綟

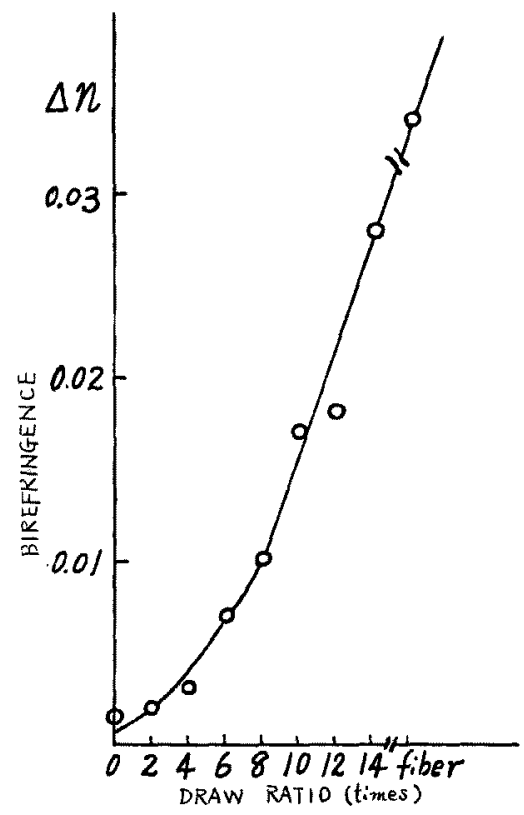

Fig. 9. Relation between the birefringence and draw ratio.

フィブロイン分子が水に分散することから䀳水性の基を 持つ $\alpha$-poly-L-alanineを内側に，他の親水性の基をむ つアミノ酸残基は外側に配位した球状粒子として存在し ているものと推定ざれる。このことはX線散乱現象が物 質を搆成している原子の有する電子密度の差に由来する ことを考えると、球状粒子と粓子の間には当然暼子密度 の粗なる部分を想像することができる。

絹类腺内に扎いて絹フィブロイン分子は膨潤した状態 で球状構造をとり，水分子によって包含されている。 （水は $70 \%$ を占める）これが前部糸腺汇送りこまれる と,フィブロイン分子は randomな $\beta$ 構造をとりなが ら吐系部に向ら。しかし配向の認められないことは生理 的食塩水の中で事体を解剖し，絹采腹内膜上り流出する フィブロイン濃原溶液をクロスニコル下で観察すると視 野が腤黒になることから明らかである。配向現象の誌め られるのは圧系部を過ぎてからであるあ。こよらに水 分を含んだ状態で吐䒺された瀻維は当然内藏する乐分を 放出する。これがボイドの形成にあずかるのである。そ こで延伸にともないこれらボイドがどのよらに変化する か液状綟より各種倍率のテグスを作製し椮討した。

第 10 図に延伸比の異なる小角散乱像を示す。延伸倍

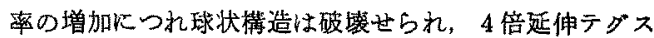
では赤道線上Kストリータが現われ始める。惩伸倍率の 增すにつれ広角侧へ伸びる。それと同時に子午線上にも 
(13)
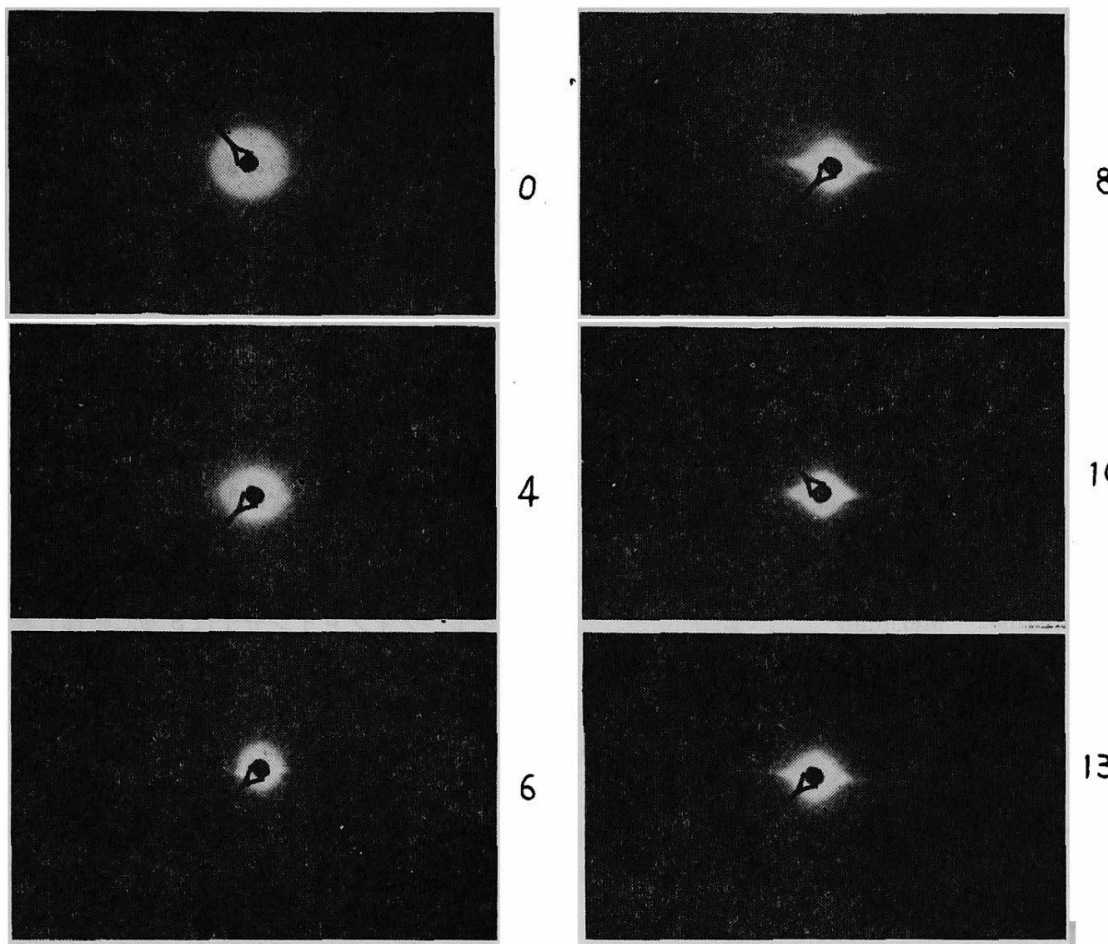

8

Fig. 10. Small angle X-ray scattering patterns of Tussah silk guts drawn at various ratios.

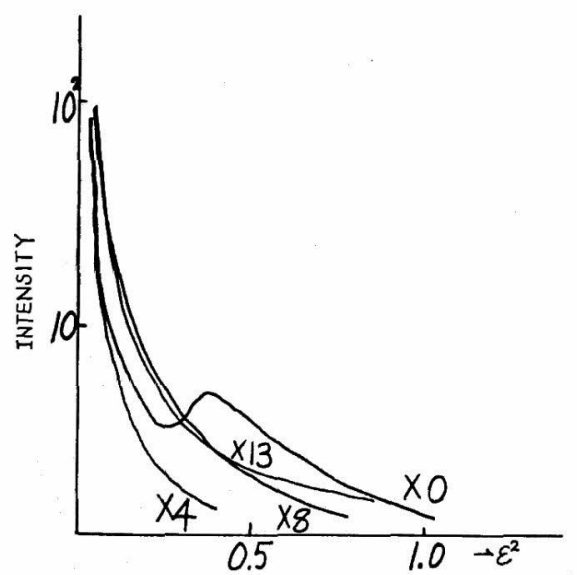

Fig. 11. Small angle $\mathrm{X}$-ray diffraction curves of original and drawn silkguts. Logarithms of the diffraction intensities are shown against the square of the angle.

同様の傾向が表われる。

種々延伸倍率を変总て測定したフィブロインの散乱強 度の対数を散乱角の二乗に対しプロットしたものが第11 図である。未延伸凝固フィブロインにおけるピークはブ

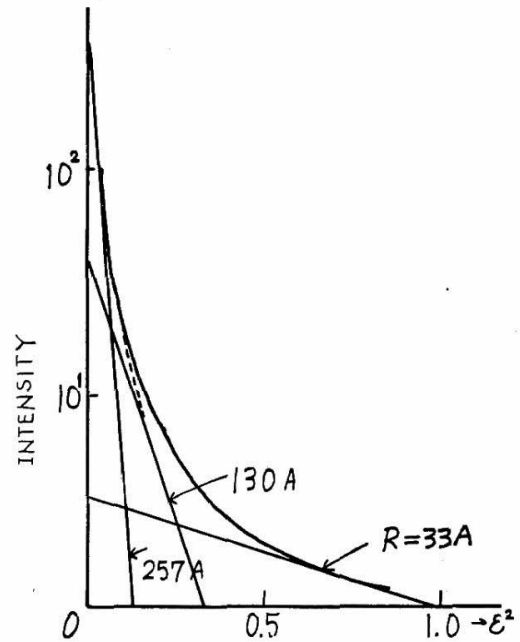

Fig. 12. Analysis of equatorial diffuse scattering of Tussah silkgut $(\times 13)$

ラック角より計算すると $240 \mathrm{~A}$ に相当する。延伸倍率の 増加につれ散乱強度は増加する。

第 12 図は 13 倍に延伸したテグスの強度分布曲線よ り Statton') がセルローズ織維に適用した Fankuchen 
Table 1. Distribution of void size in Tussah silk gut

\begin{tabular}{c|c|c}
\hline draw ration & void size (A) & $\%$ \\
\hline \multirow{2}{*}{4} & 62 & 20 \\
& 194 & 80 \\
\hline \multirow{3}{*}{8} & 42 & 43 \\
& 128 & 25 \\
& 267 & 32 \\
\hline \multirow{3}{*}{13} & 33 & 70 \\
& 130 & 12 \\
& 257 & 18 \\
\hline
\end{tabular}

Table 2. Length of microvoid

\begin{tabular}{c|c|c|c}
\hline $\begin{array}{c}\text { Extension } \\
\text { ratio }\end{array}$ & Equator & Meridian & $\begin{array}{c}\text { Ratio of Meridian } \\
\text { to Equator }\end{array}$ \\
\hline 8 & $316 \mathrm{~A}$ & $441 \mathrm{~A}$ & 1.4 \\
13 & $220 \mathrm{~A}$ & $441 \mathrm{~A}$ & 2.0 \\
\hline
\end{tabular}

Fig. 13. Schematic illustration of low angle diffuse scattering of Tussah silk gut.

の方法により void の径を求めたものである。

この方法により void の径を求め比較したるのが第 1 表である。延伸倍率の增加に伴ない void の径の小さい むのの割合が多くなる。綟系の形成過程より，はじめ水 分を含球状構造をとっていたフィブロイン分子は水分 を放出するため空隙を生ずる。この含有する水は低配向 の場合には内部から外部への発散は就そいか゚，高延伸さ れると，はしき出される速度もはやく，形成されたフィ ブリルも接近され易い。すなわち緎度が小さくなれば， void 少さくなる。

つぎに延伸に伴ないvoid の形がぞのよらに変化する かを赤道線上と子午線上のストリーク（第 13 図）の端 を基準にして Bragg の法則から voidを円柱状と仮定 し軸比を算出した。（第 2 表）8倍に比し 13 倍では瀻 維軸方向にのびている。その㭙の軸比は 2 である。それ 故 void はそれはど長いものではなく軸比より考え延伸 は void の体皘を一定とすれば表面積を最小にする方向 に作用するものと思われる。W. M. Kaeppner7) のビス コースレーヨンタイヤコードの voids に関する電子预
徽鏡的観察によると，絨維の横断面に見られる voidsの 形は结とえど棈円形を呈し，長軸は緎維軸方向に存在 しそその軸比は 2〜3である。これは上記絹の小角散乱 像からの voidsに関する考察とほぼ一致する結果を得て いる。

\section{4. と め}

柞䖯絹系腺内液状綟を延伸することにより内部棈造が どのよらに変化するが， $\alpha-\beta$ 転移と void の形成に焦 点を合せ実験を行なった。

1. 末延伸凝固フィブロインはたやすく我に溶解する ことから，眯水性の基を内側に，親水性の基を外側に向 け球状（半径 $240 \mathrm{~A}$ ) に水分子にとりかこまれて結晶化 しているるのと考党る。液状絹を延伸すると， $\alpha$-belix 構造をむつフィプロイン分子は $\beta$ 型に転移し始め， 6 ～ 8 倍に延伸する上 $\beta$-rich になる。14 倍に延伸してるな お $\alpha$ 型檴造の残存が認められる。

結晶化度は末延伸凝固フィブロインでは $36 \%$ である が延伸倍率をあげると娍少し 6〜8 倍で最小值を示し， 以後増加一る。これに反し複屈折は延伸に伴小条々に增 加する。

2. フィプロインの延伸に伴う小角散乱像の変化を追 跡すると，延伸に上り球状構造は破壊され，赤道線上に ストリークが現放る。なお延伸するとストリークは広 角側に伸び，それと同時に子午線上にも現われる。

ボイドを円柱状と仮定すると，延伸にともないvoid の径の小さいるのの割合が增加し，軸比は 2 K近ずく。

付記 本論文は 1968 年高分子年次大会で発表した。 小角散乱像の解析に当り大阪大学工学部笠牛糃民教授に ご助言をいただいた，感謝の意を表します。な打終始ご 指導をたま加っている愛知界立芸術大学教授贵祐吉博士 にお礼申しあげます。

最後にミクロトームをかしていたな゙き試料作成汇些り ご指導いただいた坂口龍三教授に和礼申しあげます。

$$
\text { 文献 }
$$

1）吳佑吉；高分子夏期大学テキスト，11，276(1963)

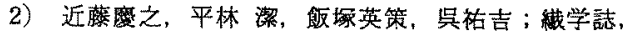
23, 311 (1967)

3）坂口育三；博士諭交（九大），141（1968）

4）宮沢辰婎；化学と工業，15，137（1962）

5）石川博, 平林 潔，近田淳雄，今井信昭; 第18 回高分子学会年次大会, 洪演要旨集, 399 (1969)

6) W. O.Statton ; J. Polymer Sci., 22, 385 (1956)

7) W. M. Kaeppner; Textile Res. J., 38, 662 (1968) 